\title{
Becoming Human
}





\title{
Becoming Human
}

\author{
A THEORY OF ONTOGENY
}

Q0

Michael Tomasello

The Belknap Press of

Harvard University Press

Cambridge, Massachusetts

London, England

2019 
Copyright (C) 2019 by the President and Fellows of Harvard College All rights reserved

Printed in the United States of America

First printing

Art: Yellow Journey (oil on canvas) (C) Charlie Millar, courtesy of Bridgeman Fine Art Design: Tim Jones

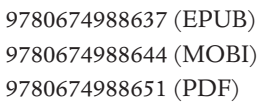

The Library of Congress has cataloged the printed edition as follows: Names: Tomasello, Michael, author.

Title: Becoming human : a theory of ontogeny / Michael Tomasello.

Description: Cambridge, Massachusetts : The Belknap Press of Harvard University Press, 2019.

Includes bibliographical references and index.

Identifiers: LCCN 2018014212 | ISBN 9780674980853 (hardcover : alk. paper)

Subjects: LCSH: Developmental psychology. | Ontogeny. | Socialization.

Evolutionary psychology. | Behavior evolution.

Classification: LCC BF713 .T655 2019 | DDC 155-dc23

LC record available at https:/ / lccn.loc.gov/2018014212 
For the Leipzig Team 
